\title{
Analisis Laporan Keuangan Berdasarkan Rasio Likuiditas, Solvabilitas dan Profitabilitas terhadap Kinerja Keuangan pada Badan Penyelenggara Jaminan Sosial (BPJS) Ketenagakerjaan
}

\author{
*Syahrina Ramadhani, Kusni Hidayati, Nova Retnowati \\ Program Studi Akuntansi Fakultas Ekonomi dan Bisnis \\ Universitas Bhayangkara Surabaya, Indonesia
}

DOI: $10.46821 /$ equity.v1i2.172

\begin{abstract}
ABSTRAK
Badan Penyelenggara Jaminan Sosial (BPJS) Ketenagakerjaan merupakan suatu badan usaha milik pemerintah yang berfungsi untuk menyelenggarakan program jaminan tenaga kerja. Untuk dapat bersaing dalam dunia usaha, agar tetap bertahan dan berkembang dapat ditentukan melalui kemampuan suatu perusahaan dengan mencermati kondisi dan kinerja keuangan. Penelitian ini bertujuan untuk mengetahui kinerja keuangan dilihat dari hasil analisis laporan keuangan berdasarkan rasio likuiditas, rasio solvabilitas dan rasio profitabilitas. Jenis data yang digunakan adalah data sekunder dengan teknik pengumpulan data berupa dokumen dan studi pustaka. Teknik analisis data yang digunakan adalah deskriptif analitis. Berdasarkan hasil penelitian dapat disimpulkan bahwa kinerja keuangan BPJS Ketenagakerjaan pada tahun 2014-2016 adalah cenderung berfluktuasi namun dinilai cukup baik dan perlu adanya peningkatan.
\end{abstract}

Kata Kunci: Laporan Keuangan, Rasio Likuiditas, Rasio Solvabilitas, Rasio Profitabilitas dan Kinerja Keuangan

\begin{abstract}
Badan Penyelenggara Jaminan Sosial (BPJS) Ketenagakerjaan is a governmentowned enterprise that serves to organize a labor guarantee program. To be able to compete in the business world, to survive and develop can be determined through the ability of a company by looking at the conditions and financial performance. This study aims to determine the financial performance seen from the analysis of financial statements based on liquidity ratios, solvency ratios and profitability ratios. The type of data used is secondary data with data collection techniques in the form of documents and literature study. Data analysis technique used is descriptive analytical. Based on the results of the study can be concluded that the financial performance BPJS Ketenagakerjaan in 2014-2016 is likely to fluctuate but considered quite good and need an increase.
\end{abstract}

Keywords: Financial Report, Liquidity Ratio, Solvency Ratio, Profitability Ratio and Financial Performance

*Corresponding Author:

Email: syahrinadhani@gmail.com 


\section{PENDAHULUAN}

Diera globalisasi saat ini, Indonesia dihadapkan oleh berbagai persaingan utamanya dalam bidang ekonomi. Untuk menjaga perkembangan dan kelangsungan hidup suatu usaha perlu adanya upaya yang harus dilakukan oleh pihak-pihak yang berkepentingan. Salah satunya yaitu manajemen perusahaan yang harus dapat menyusun rencana untuk perusahaan menjadi yang lebih baik dari periode-periode sebelumnya dengan memperbaiki sistem pengawasan dan menentukan kebijakan-kebijakan yang tepat serta harus dapat mengukur kemampuan perusahaan dengan memperbaiki kondisi keuangan dalam hal efektivitas dan efesiensi.

Salah satu cara untuk mengetahui kondisi suatu perusahaan dapat dilihat melalui laporan keuangannya. Laporan keuangan merupakan alat yang penting untuk memperoleh informasi sehubungan dengan kondisi keuangan dikarenakan dapat memberikan informasi-informasi mengenai posisi keuangan suatu perusahaan sehingga digunakan sebagai media untuk mengukur kinerja keuangan dan memberikan informasi keuangan kepada pihak-pihak yang berkepentingan sebagai pertimbangan dalam pembuatan keputusan-keputusan ekonomi.

Rasio keuangan adalah salah satu jenis alat ukur yang digunakan perusahaan untuk menganalisis laporan keuangan. Dengan menggunakan rasio keuangan dapat menganalisa baik atau buruknya keadaan posisi keuangan suatu perusahaan dari suatu periode ke periode berikutnya. Rasio yang digunakan yaitu rasio likuiditas, rasio solvabilitas dan rasio profitabilitas.

Dalam pembukaan Undang-Undang Dasar Negara Republik Indonesia Tahun 1945 diamanatkan bahwa tujuan negara adalah untuk keadilan sosial dan meningkatkan kesejahteraan bangsa Indonesia. Dalam perubahan ke empat Undang-Undang Dasar Negara Republik Indonesia Tahun 1945, tujuan tersebut semakin dipertegas yaitu dengan mengembangkan sistem jaminan sosial bagi kesejahteraan seluruh rakyat Indonesia.

Diamanatkan dalam Undang-Undang No.40 tahun 2004 tentang Sistem Jaminan Sosial Nasional yang kemudian ditindaklanjuti dengan terbitnya UndangUndang Nomor 24 Tahun 2011 tentang badan penyelenggara jaminan sosial, pemerintah mewajibkan kepada seluruh perusahaan atau pemberi kerja untuk dapat mengikut sertakan pekerja atau buruhnya sebagai peserta Badan Penyelenggara Jaminan Sosial (BPJS).

Badan Penyelenggara Jaminan Sosial (BPJS) Ketenagakerjaan merupakan program pemerintah yang sejak periode 1 Januari 2014 ditetapkan sebagai pengganti PT Jamsostek (persero). Dengan tujuan yang sama yaitu memberikan perlindungan bagi tenaga kerja untuk mengatasi resiko sosial ekonomi tertentu dan penyelenggaraannya menggunakan mekanisme peningkatan kesejahteraan sosial.

Penilaian kinerja keuangan memiliki peran penting dalam memberikan informasi mengenai keadaan yang sedang dialami oleh suatu perusahaan. Terlebih lagi demi mewujudkan visi dan misi yang telah ditetapkan. Pada BPJS Ketenagakerjaan yang merupakan program pemerintah hendaklah tetap terus melakukan perbaikan untuk perkembangan program jaminan dan sebesarsebesarnya untuk kepentingan pesertanya.

Pada kenyataannya program jaminan sosial yang mewajibkan kepada seluruh perusahaan atau pemberi kerja mendaftarkan para pekerja atau buruhnya 
namun tidak semua perusahaan atau pemberi kerja melaksanakan peraturan tersebut. Alasannya perusahaan merupakan suatu badan usaha yang menginginkan mengeluarkan biaya sekecil-kecilnya dan mendapatkan keuntungan sebesarbesarnya. Dengan mencari alternatif lain untuk pendaftaran jaminan sosial untuk para pekerjanya yang relatif dinilai lebih rendah dibanding dengan tarif iuran yang terdapat di BPJS Ketenagakerjaan. Sehingga para pengusaha memilih mendaftarkan sebagian pekerja atau buruhnya dalam program jaminan sosial yang diwajibkan oleh pemerintah tersebut.

Dengan latar belakang tersebut, penelitian ini memiliki rumusan masalah yakni bagaimana hasil analisis laporan keuangan berdasarkan rasio likuiditas, solvabilitas dan profitabilitas terhadap kinerja keuangan pada Badan Penyelenggara Jaminan Sosial (BPJS) Ketenagakerjaan?. Adapun tujuan penelitian ini yaitu untuk mengetahui kinerja keuangan dilihat dari hasil analisis laporan keuangan berdasarkan rasio likuiditas, solvabilitas dan profitabilitas pada Badan Penyelenggara Jaminan Sosial Ketenagakerjaan.

\section{LANDASAN TEORI}

\section{Laporan Keuangan}

Menurut Hery (2016:3) menerangkan bahwa laporan keuangan adalah hasil dari proses akuntansi yang dapat digunakan sebagai alat untuk mengkomunikasikan data keuangan atau aktivitas perusahaan kepada pihak-pihak yang berkepentingan sedangkan menurut Pernyataan Standar Akuntansi Keuangan (PSAK) No.1 (2017), laporan keuangan adalah suatu penyajian terstruktur dari posisi keuangan dan kinerja keuangan suatu entitas.

\section{Analisis Laporan Keuangan}

Analisis laporan kuangan merupakan analisis yang dilakukan dengan membandingkan unsur-unsur tertentu yang terdapat pada laporan keuangan untuk mengetahui perkembangan mengenai kondisi dan kinerja suatu perusahaan.

Menurut Dermawan dan Djahotman (2013:1) mendefinisikan analisis laporan keuangan (financial statement analysis) adalah aplikasi dari alat dan teknik analisis untuk laporan keuangan bertujuan umum dan data-data yang berkaitan untuk menghasilkan estimasi dan kesimpulan yang bermanfaat dalam analisis bisnis.

Menurut Hanafi dan Halim (2016:20) menyatakan bahwa analisis keuangan pada dasarnya ingin melihat prospek dan risiko perusahaan. Prospek bisa dilihat dari tingkat keuntungan (profitabilitas) dan risiko bisa dilihat dari kemungkinan perusahaan mengalami kesulitan keuangan atau mengalami kebangkrutan.

\section{Rasio Keuangan}

Menurut James dalam Kasmir (2017:104) rasio keuangan merupakan indeks yang menghubungkan dua angka akuntansi dan diperoleh dengan membagi satu angka dengan angka lainnya.

Fahmi (2013:108) mengemukakan rasio keuangan adalah instrumen analisis prestasi perusahaan yang menjelaskan berbagai hubungan dan indikator keuangan, untuk menunjukkan perubahan dalam kondisi keuangan atau prestasi operasi di masa lalu dan membantu menggambarkan trend pola perubahan tersebut, untuk kemudian menunjukkan risiko dan peluang yang melekat pada perusahaan yang bersangkutan. 


\section{Jenis-jenis Rasio Keuangan}

\section{Rasio Likuiditas}

Menurut Fred Weston dalam Kasmir (2017:129) menyebutkan bahwa rasio likuiditas (liquidity ratio) merupakan rasio yang menggambarkan kemampuan perusahaan dalam memenuhi kewajiban (utang) jangka pendek.

a. Rasio Lancar (current ratio)

Rasio lancar atau (current ratio) merupakan rasio yang digunakan untuk mengukur kemampuan suatu perusahaan dalam memenuhi kewajiban jangka pendeknya terutama kewajiban yang segera jatuh tempo.

Current Ratio $=\frac{\text { Aktiva lancar }(\text { Current Assets })}{\text { Utang lancar }(\text { Current Liabilities })}$

b. Rasio Cepat (Quick Ratio)

Rasio Cepat (Quick Ratio) atau rasio sangat lancar arau acid test ratio merupakan rasio yang menunjukkan kemampuan perusahaan dalam memenuhi atau membayar kewajiban atau utang lancar (utang jangka pendek) dengan aktiva lancar tanpa memperhitungkan nilai persediaan (inventory).

$$
\text { Quick Ratio }=\frac{\text { Kas + Bank + Efek + Piutang }}{\text { Utang lancar (Current Liabilities) }}
$$

c. Rasio Kas (Cash Ratio)

Rasio Kas (Cash Ratio) merupakan alat yang digunakan untuk mengukur seberapa besar uang kas yang tersedia untuk membayar utang.

$$
\text { Cash Ratio }=\frac{\text { Kas }+ \text { Bank }}{\text { Utang lancar (Current Liabilities) }}
$$

\section{Rasio Solvabilitas}

Rasio solvabilitas atau rasio leverage menurut Fahmi (2014:62), adalah mengukur seberapa besar perusahaan dibiayai dengan utang. Menurut Kasmir (2017:156) perusahaan dapat menggunakan rasio sebagai berikut:

a. Debt to Asset Ratio (Debt Ratio)

Debt ratio merupakan rasio utang yang digunakan untuk mengukur perbandingan antara total utang dengan total aktiva. Dengan kata lain, untuk mengukur seberapa besar aktiva perusahaan dibiayai oleh utang atau seberapa besar utang perushaan berpengaruh terhadap pengelolaan aktiva.

Debt to asset ratio $=\frac{\text { Total Debt }}{\text { Total Assets }}$


b. Debt to Equity Ratio

Debt to equity ratio merupakan rasio yang digunakan untuk menilai utang dengan ekuitas sehingga dapat mengetahui jumlah dana yang disediakan peminjam (kreditor) dengan pemilik perusahaan.

Debt to to equity ratio $=\frac{\text { Total Debt }}{\text { Ekuitas (Equity) }}$

\section{Rasio Profitabilitas}

Menurut Kasmir (2017:196), Rasio profitabilitas merupakan rasio untuk menilai kemampuan perusahaan dalam mencari keuntungan. Rasio ini juga memberikan ukuran tingkat efektifitas manajemen suatu perusahaan. Dalam melakukan pengukuran rasio profitabilitas suatu perusahaan menurut Kasmir (2017:201) dapat menggunakan rasio sebagai berikut:

a. Hasil Pengembalian Investasi (Return on Investment/ROI)

Hasil pengembalian investasi Return on Investment (ROI) atau return on total assets merupakan rasio yang menunjukkan hasil (return) atas jumlah aktiva yang digunakan dalam perusahaan. ROI juga merupakan suatu ukuran tentang efektivitas manajemen dalam mengelola investasinya.

Return on Investment $(\mathrm{ROI})=\frac{\text { Earning After Interest and Tax }}{\text { Total assets }}$

b. Hasil Pengembalian Ekuitas (Return on Equity/ROE)

Hasil pengenembalian ekuitas atau return on Equity atau rentabilitas modal sendiri merupakan rasio untuk mengukur laba bersih sesudah pajak dengan modal sendiri. Rasio ini menunjukkan efisiensi penggunaan modal sendiri.

Return on Equity $(\mathrm{ROE})=\frac{\text { Earning After Interest and Tax }}{\text { Total Equity }}$

\section{Kinerja Keuangan}

Menurut Rudianto (2013:189), kinerja keuangan adalah hasil atau prestasi yang telah dicapai oleh manajemen perusahaan dalam menjalankan fungsinya mengelola aset perusahaan secara efektif selama periode tertentu. Sedanngkan menurut Sutrisno (2009:53), kinerja keuangan adalah prestasi yang dicapai perusahaan dalam suatu periode tertentu yang mencerminkan tingkat kesehatan perusahaan tersebut. Berdasarkan beberapa pengertian diatas dapat disimpulkan bahwa kinerja keuangan adalah analisis yang digunakan untuk melihat hasil prestasi yang telah dicapai oleh pihak manajemen dalam mengelola suatu perusahaan. 


\section{METODE PENELITIAN}

\section{Variabel Dependen}

Pendekatan penelitian yang dilakukan dalam penelitian ini adalah pendekatan kualitatif dan menggunakan metode deskriptif, yaitu salah satu jenis penelitian yang tujuannya untuk menyajikan gambaran lengkap mengenai setting sosial atau dimaksudkan untuk eksplorasi dan klarifikasi mengenai suatu fenomena atau kenyataan sosial, dengan cara mendeskripsikan sejumlah variabel yang berkenaan dengan masalah dan unit yang diteliti antara fenomena yang diuji.

Sumber data yang digunakan peneliti yaitu sumber data sekunder yakni peneliti peroleh melalui situs resmi Badan Penyelenggara Jaminan Sosial (BPJS) Ketenagakerjaan berupa laporan keuangan tahun 2014 sampai dengan tahun 2016 dan deskripsi yang berhubungan dengan obyek penelitian serta teknik pengumpulan data yang digunakan peneliti yaitu dokumen dan studi kepustakaan.

Teknik analisa data yaitu melakukan analisis terhadap laporan keuangan dengan menggunakan rasio keuangan yaitu rasio likuiditas (rasio lancar, rasio cepat dan rasio kas), rasio solvabilitas (hutang terhadap aset dan hutang terhadap ekuitas) dan rasio profitabilitas (hasil pengembalian investasi dan hasil pengembalian ekuitas) selanjutnya melakukan perbandingan untuk setiap periode dan kemudian melakukan interpretasi kinerja keuangan serta mengambil kesimpulan.

$$
\begin{aligned}
& \text { HASIL DAN PEMBAHASAN } \\
& \text { Analisis Rasio Likuiditas } \\
& \text { Rasio Lancar (Current Ratio) } \\
& \text { Tahun } 2014=\frac{8.277 .738 .484 .037}{1.056 .851 .073 .548}=783,25 \% \\
& \text { Tahun } 2015=\frac{7.310 .709 .056 .605}{913.705 .890 .139}=800,12 \% \\
& \text { Tahun } 2016=\frac{7.198 .324 .828 .197}{1.301 .501 .324 .593}=553,08 \%
\end{aligned}
$$

Berdasarkan hasil perhitungan dapat dianalisis bahwa rasio lancar Badan Penyelenggara Jaminan Sosial Ketenagakerjaan cenderung mengalami kenaikan dan penurunan selama tiga tahun terakhir terbukti pada tahun 2015 mengalami kenaikan sebesar $16,87 \%$ dari tahun 2014 yaitu $783,25 \%$ menjadi $800,12 \%$ pada tahun 2015. Namun pada tahun 2016 mengalami penurunan sebesar 247,04\% dari tahun 2015 800,12\% menjadi 553,08\%. Meskipun hasil pengukuran rasio lancar yang diperoleh selama tahun 2014 hingga 2016 mengalami fluktuasi, kondisi perusahaan dinilai cukup baik karena hasil yang diperoleh melebihi standar yang ditentukan yaitu 200\% (Kasmir, 2017:135) dan semakin besar hasil perbandingan maka semakin baik perusahaan dalam memenuhi kewajiban jangka pendeknya.

\section{Rasio Cepat (Quick Ratio)}

Berdasarkan hasil perhitungan dapat dianalisis bahwa rasio cepat Badan Penyelenggara Jaminan Sosial Ketenagakerjaan cenderung mengalami penurunan 
selama tiga tahun terakhir terbukti pada tahun 2014 sampai dengan 2016 yakni sebesar 526,93\%, 467,94\% dan turun lagi menjadi 354,50\%. Hal ini menunjukkan bahwa kemampuan perusahaan untuk memenuhi atau membayar hutang jangka pendeknya selama tiga tahun dimulai berlakukan BPJS Ketenagakerjaan juga menurun. Namun dengan melihat hasil yang diperoleh BPJS Ketenagakerjaan cukup baik dalam mengolah tingkat likuiditasnya karena rasio cepat yang dicapai telah melebihi standar yang telah ditentukan yakni sebesar 100\% (Fahmi, 2014:62).

Tahun $2014=\frac{1.444 .063 .104 .182+3.027 .512 .354 .352+1.097 .259 .456 .075}{1.056 .851 .073 .548}=526,93 \%$
Tahun $2015=\frac{1.244 .955 .540 .872+2.139 .789 .479 .872+890.809 .066 .806}{913.705 .890 .139}=467,94 \%$
Tahun 2016 $=\frac{1.540 .586 .319 .642+2.213 .660 .839 .975+859.604 .452 .135}{1.301 .501 .324 .593}=354,50 \%$

\section{Rasio Kas (Cash Ratio)}

Berdasarkan hasil perhitungan dapat dianalisis bahwa rasio kas Badan Penyelenggara Jaminan Sosial Ketenagakerjaan dari tahun 2014 sampai dengan tahun 2016 mengalami penurunan secara terus menerus. Pada tahun 2015 mengalami penurunan sebesar 0,39\% dari tahun 2014 yakni pada 136,64\% menjadi 136,25\%. Dan pada tahun 2016 mengalami penurunan kembali sebesar 17,88\% dari tahun 2015 sebesar 136,25\% menjadi 118,37\%. Hal ini menunjukkan bahwa Badan Penyelenggara Jaminan (BPJS) Ketenagakerjaan dalam memenuhi hutang jangka pendeknya dengan kas dinilai menurun namun masih dalam kondisi aman dan penurunan yang terjadi tidak begitu signifikan.

$$
\begin{aligned}
& \text { Tahun } 2014=\frac{1.444 .063 .104 .182}{1.056 .851 .073 .548}=136,64 \% \\
& \text { Tahun } 2015=\frac{1.244 .955 .540 .872}{913.705 .890 .139}=136,25 \% \\
& \text { Tahun 2016 }=\frac{1.540 .586 .319 .642}{1.301 .501 .324 .593}=118,37 \%
\end{aligned}
$$

\section{Analisis Rasio Solvabilitas \\ Rasio Hutang terhadap Aset}

Berdasarkan hasil perhitungan dapat dianalisis bahwa rasio hutang terhadap aset Badan Penyelenggara Jaminan Sosial Ketenagakerjaan dari tahun 2014 sampai dengan tahun 2016 mengalami penurunan dan kenaikan. Pada tahun 2015 mengalami penurunan sebesar 0,4\% dari tahun 2014 yakni sebesar 19,96\% menjadi 19,56\%. Pada tahun 2016 mengalami peningkatan sebesar 0,19\% dari tahun 2015 yakni sebesar 19,56\% menjadi 19,75\%.Kenaikan dan penurunan ini dinilai cenderung relatif stabil tidak signifikan. Hal ini menunjukkan bahwa 
Badan Penyelenggara Jaminan Sosial (BPJS) Ketenagakerjaan dalam pengelolaan total aktiva dan total utang cukup baik dan dalam mempertahankan selama tiga tahun diberlakukannya relatif stabil sehingga dinilai mampu menutupi hutang dengan aktiva yang dimilikinya.

$$
\begin{aligned}
& \text { Tahun } 2014=\frac{2.311 .006 .830 .828}{11.581 .019 .857 .220}=19,96 \% \\
& \text { Tahun 2015 }=\frac{2.167 .696 .548 .140}{11.080 .636 .007 .966}=19,56 \% \\
& \text { Tahun 2016 }=\frac{2.641 .272 .741 .627}{13.371 .558 .956 .031}=19.75 \%
\end{aligned}
$$

\section{Rasio Hutang terhadap Ekuitas}

Berdasarkan hasil perhitungan dapat dianalisis bahwa rasio hutang terhadap ekuitas Badan Penyelenggara Jaminan Sosial Ketenagakerjaan dari tahun 2014 sampai dengan tahun 2016 mengalami penurunan dan peningkatan. Pada tahun 2015 mengalami penurunan sebesar $0,61 \%$ dari tahun 2014 yakni sebesar $24,93 \%$ menjadi $24,32 \%$. Pada tahun 2016 mengalami peningkatan sebesar $0,3 \%$ dari tahun 2015 sebesar 24,32\% menjadi 24,62\%. Kenaikan dan penurunan ini dinilai cenderung relatif stabil tidak signifikan. Hal tersebut menunjukkan bahwa Badan Penyelenggara Jaminan Sosial (BPJS) Ketenagakerjaan dalam pengelolaan total ekuitas dan total utang cukup baik serta dalam mempertahankan selama tiga tahun diberlakukannya relatif stabil sehingga dinilai mampu menutupi hutang dengan menggunakan modal sendiri.

$$
\begin{aligned}
& \text { Tahun } 2014=\frac{2 \cdot 311 \cdot 006 \cdot 830.828}{9 \cdot 270 \cdot 013 \cdot 026 \cdot 392}=24,93 \% \\
& \text { Tahun } 2015=\frac{2 \cdot 167 \cdot 696.548 .140}{8 \cdot 912.939 .459 .826}=24,32 \% \\
& \text { Tahun 2016 }=\frac{2 \cdot 641 \cdot 272.741 .627}{10.730 .286 .214 .405}=24,62 \%
\end{aligned}
$$

\section{Analisis Rasio Profitabilitas}

\section{Hasil Pengembalian Investasi (Return On Investment)}

Berdasarkan hasil perhitungan dapat dianalisis bahwa rasio hasil pengembalian investasi (Return On Investment) Badan Penyelenggara Jaminan Sosial Ketenagakerjaan dari tahun 2014 sampai dengan tahun 2016 mengalami penurunan dan kenaikan. Pada tahun 2015 mengalami penurunan sebesar 0,52\% dari tahun 2014 yakni sebesar 6,16\% menjadi 5,64\%. Dan pada tahun 2016 mengalami kenaikan sebesar 3,81\% dari tahun 2015 yakni 5,64 menjadi 9,45\%. Hal ini menunjukkan bahwa tingkat profitabilitas cenderung berfluktuasi dan 
dinilai masih cukup rendah. Namun pada dasarnya Badan Penyelenggara Jaminan Sosial Ketenagakerjaan merupakan badan hukum berbentuk nirlaba yakni hasil pengelolaan dana jaminan sosial seluruhnya untuk pengembangan program dan sebesar-besarnya kepentingan peserta.

Tahun 2014 $=\frac{712 \cdot 931 \cdot 449 \cdot 004}{11 \cdot 581 \cdot 019 \cdot 857 \cdot 220}=6,16 \%$
Tahun 2015 $=\frac{624 \cdot 615 \cdot 414.495}{11 \cdot 080 \cdot 636 \cdot 007 \cdot 966}=5,64 \%$
Tahun 2016 $=\frac{1 \cdot 263 \cdot 186 \cdot 304 \cdot 437}{13 \cdot 371 \cdot 558 \cdot 956 \cdot 031}=9,45 \%$

\section{Hasil Pengembalian Ekuitas (Return On Equity)}

Berdasarkan hasil perhitungan dapat dianalisis bahwa rasio Hasil Pengembalian Ekuitas (Return On Equity) Badan Penyelenggara Jaminan Sosial Ketenagakerjaan dari tahun 2014 sampai dengan tahun 2016 mengalami penurunan dan kenaikan pada tahun 2015 mengalami penurunan sebesar 0,68\% dari tahun 2014 yaitu sebesar 7,69\% menjadi 7,01\%. Dan tahun 2016 mengalami kenaikan sebesar 4,76\% yakni dari tahun 2015 sebesar 7,01\% menjadi $11,77 \%$.Hal ini menunjukkan bahwa tingkat profitabilitas yang dimiliki Badan Penyelenggara Jaminan Sosial (BPJS) Ketenagakerjaan cenderung berfluktuasi dan hasil perhitungan rasio ini terlihat bahwa perusahaan dalam mencapai tingkat pengembalian ekuitas semakin membaik.

$$
\begin{aligned}
& \text { Tahun } 2014=\frac{712 \cdot 931 \cdot 449 \cdot 004}{9 \cdot 270 \cdot 013 \cdot 026 \cdot 392} \quad=7,69 \% \\
& \text { Tahun } 2015=\frac{624 \cdot 615 \cdot 414.495}{8 \cdot 912 \cdot 939 \cdot 459.826}=7,01 \% \\
& \text { 1.263.186.304.437 } \\
& \text { Tahun } 2016=\frac{1.263 .186 .304 .437}{10.730 .286 .214 .405} \quad=11,77 \%
\end{aligned}
$$

\section{SIMPULAN}

Hasil perhitungan laporan keuangan berdasarkan rasio likuiditas kinerja keuangan Badan Penyelenggara Jaminan Sosial Ketenagakerjaan pada tahun 2014 hingga tahun 2016 mengalami fluktuasi disebabkan oleh meningkatnya dan menurunnya jumlah hutang lancar dan aktiva lancar. Hal ini dapat dilihat dari perhitungan rasio lancar (current ratio) yang mengalami kenaikan dan penurunan. Sedangkan pada perhitungan rasio cepat (quick ratio) terjadi penurunan secara terus menerus. Begitu pula pada perhitungan rasio kas (cash ratio) yang terjadi penurunan secara terus menerus meskipun tidak signifikan. Namun secara keseluruhan rasio 
likuiditas cenderung membaik karena hasil yang diperoleh telah melebihi standar yang telah ditetapkan. Hasil perhitungan laporan keuangan berdasarkan rasio solvabilitas kinerja keuangan Badan Penyelenggara Jaminan Sosial Ketenagakerjaan pada tahun 2014 hingga tahun 2016 mengalami fluktuasi namun cenderung stabil disebabkan oleh meningkatnya dan menurunnya total hutang, total aset dan total ekuitas. Berdasarkan perhitungan rasio hutang terhadap aset (debt to asset ratio) menunjukkan bahwa Badan Penyelenggara Jaminan Sosial Ketenagakerjaan mampu memenuhi hutang jangka pendek dan panjangnya serta mampu menunjukkan aktiva yang dimiliki melebihi hutangnya. Begitu pula rasio hutang terhadap ekuitas (debt to equity ratio) yang menunjukkan bahwa Badan Penyelenggara Jaminan Sosial Ketenagakerjaan yang mempunyai porsi aman dalam memenuhi hutang terhadap modal sendiri. Hasil perhitungan laporan keuangan berdasarkan rasio profitabilitas kinerja keuangan Badan Penyelenggara Jaminan Sosial Ketenagakerjaan pada tahun 2014 hingga tahun 2016 mengalami fluktuasi yang disebabkan oleh meningkatnya dan menurunnya penghasilan setelah pajak, total aset dan total ekuitasnya. Hal ini dapat dilihat dari perhitungan hasil pengembalian investasi (return on invesment) dan hasil pengembalian ekuitas (return on equity) yang menujukkan bahwa hasil yang diperoleh relatif rendah sehingga dapat dikatakan Badan Penyelenggara Jaminan Sosial Ketenagakerjaan dalam mencari keuntungan sangat sedikit sehingga membuktikan Badan Penyelenggara Jaminan Sosial Ketenagakerjaan merupakan badan yang patuh terhadap peraturan bahwa tidak membesarkan keuntungan yang dimiliki karena termasuk badan usaha yang bersifat nirlaba dan lebih memprioritaskan untuk kepentingan para peserta.

\section{DAFTAR PUSTAKA}

Dermawan dan Djahotman 2013, Analisis Rasio Keuangan, Mitra Wacana Media, Jakarta

Fahmi, Irham 2014, Analisis Kinerja Keuangan, Cetakan ketiga, Alfabeta, Bandung.

Hanafi dan Halim 2016, Analisis Laporan Keuangan, Cetakan Terakhir, Unit Penerbit dan Percetakan Sekolah Tinggi Ilmu Manajemen YKPN, Yogyakarta.

Hery 2016, Akuntansi Laporan Keuangan, PT. Grasindo, Jakarta.

Ikatan Akuntan Indonesia, Standar Akuntansi Keuangan Efektif per 1 Januari 2017.

Kasmir 2017, Analisis Laporan Keuangan, Cetakan ke-10, PT. Raja Grafindo Persada, Jakarta.

Rudianto 2013, Akuntansi Manajemen : Informasi untuk Pengambilan Keputusan Strategis, PT. Gelora Aksara Pratama, Jakarta. 
Sutrisno 2009, Manajemen Keuangan Teori, Konsep dan Aplikasi, Ekonisia, Yogyakarta.

Undang-Undang Nomor 24 Tahun 2011 tentang Badan Penyelenggara Jaminan Sosial. Diterbitkan oleh : Pusat Hubungan Masyarakat Kementerian Tenaga Kerja dan Transmigrasi RI. Tahun 2012. 